\title{
Conceptual Impasses: Strategies for Supporting Students in Life Narrative Courses
}

\author{
Laurie McNeill
}

University of British Columbia

A "life writing" (or "autobiography" or "personal narratives") course for undergraduates comes with such potential for transformative learning. As Kate Douglas and I have observed, because these texts are non-fiction, they provide records and stories of lives that may be totally new to students, and thus invite them to learn about and understand the perspectives and histories of others (2-6); they may also narrate lives that students share, and that identification can be affirmative or disconcerting. In my experience teaching life narratives in literary and cultural studies courses to undergraduate students at the University of British Columbia, students are typically interested in and ready to engage with the content of these texts. But they are much less prepared to work with these texts using a critical framework: they don't have one, and they don't seem to think that they need one, either. Because life narratives are texts that look like other kinds of texts, particularly their "false friend" the novel, students may feel that they already know how to approach them. On the other hand, they may resist analyzing these narratives because they are not fiction, a resistance that arises from cultural investments in "objectivity" and the status of "non-fiction" as "true" and therefore not literary or even really artful (artfulness, or imagining the writer attending to the construction of a narrative, seems to suggest "non-truth" or fiction). Given these attitudes and gaps in knowledge, I have learned to build a theoretical foundation for my courses that provides the class with a set of core concepts that make explicit the assumptions we as scholars of life narratives build on when we talk about these texts. That foundation includes foregrounding of disciplinary practices and methodologies, attending to the kinds of questions literary and cultural studies scholars would ask of these texts, 
since that is the disciplinary context from which I teach auto/biographical materials. I will share with you four of these core concepts-terminology, autobiographical truth, genre, and texts as commodities-that make up the spine of my courses, as well as an in-class exercise I've developed that helps address these and other concerns.

\section{BEING DISCIPLINED: WHAT LITERARY SCHOLARS DO WITH "AUTOBIOGRAPHY"}

I teach in the Department of English Language and Literatures, as well as in a first-year multidisciplinary program (the Coordinated Arts Program). My students are in their first- to fourth-year of their undergraduate degrees. Many but certainly not all the students are literature majors; in some of my first-year courses, at least $50 \%$ of them come from outside the Faculty of Arts, and are enrolled in sciences, forestry, engineering, and so on, because the course meets a degree requirement for "communications." Almost $100 \%$ of the students will not have taken a life writing studies course before, though a handful will have studied a life writing text in other contexts; many will not even identify that they've read one, though with some probing they will come up with a few popular texts or ones they read in high school. Because of this lack of familiarity and, as Deborah Parker has similarly observed about teaching the practice of memoir in an interdisciplinary context $(84,87)$, I provide a more explicit theoretical and methodological framework than I used to. For instance, we spend time talking about the questions literary studies scholars specifically will ask life writing texts, and how the methods of qualitative analysis that we will use to answer such questions necessarily shape both our research questions and our findings. In literary and cultural studies, I observe, we analyze the texts for the choices writers make about how to represent experience: we are not studying experience itself—and that's a disciplinary difference. I give examples of how other humanities and social science disciplines—for example, Psychology, History, or Sociology—will also use life writing texts (sometimes, the very texts we are studying) but for different purposes. Historians, for instance, may study a life writing text as a source of information about an event, rather than the object of study itself.

This focus on representation and the choices authors make in those representations, a focus that reflects methodological and disciplinary approaches, is something I return to throughout the course. I find that life writing texts-because they are based on real events-really challenge students in the kinds of research questions they themselves want to 
ask when they undertake their own textual analyses, with the result that they want to focus on "life" rather than "text." For example, in one course, I have taught Missing Sarah: A Memoir of Loss, a life narrative by Maggie de Vries about her sister, who becomes addicted to drugs and enters the sex trade. My lectures and activities ask students to examine how the memoir represents this woman's experiences-whose voices are included, how speakers are introduced, who is authorized, what content is included or excluded. Many students, however, want to write research papers on this memoir that explore why this woman became an addict-psychological or sociological questions, perhaps, but not ones answerable through textual analysis.

It is through attempting to break this conceptual impasse for students, to find ways to illuminate methodological practice and its ends, that I have come to focus on the following four concepts as ones that help shape new conversations about and analytical approaches to life narratives. While of course many other issues and ideas are germane to the field and its study, for me, early and frequent attention to these particular topics has borne fruit in making explicit my own and my students' assumptions, blindspots, and knowledge gaps about auto/biographical practices.

1. Terminology: In the first or second class of a course, we discuss the cultural history of the term "autobiography," a genre coming out of a particular socio-historic moment and reflecting a particular, exclusive type of subject. This history sets up a discussion of why terminology matters, how what something is called is part of how it is understood, or misunderstood, a conversation that anticipates our considerations of genre. What other forms of self-representation can we identify, I ask, and we brainstorm lists (diaries, status updates, documentaries, selfies ...). We group these types alongside "autobiography," with "personal narrative" and "auto/biography" as overarching terms that name this loose collective of related textual acts (I render this overarching quality literally by drawing an umbrella above the list). We attend to generic differences within this collection, thinking about ways a "memoir" is different from a "blog," and why we therefore don't simply use these terms synonymously. In underlining the point that life narrative are not novels, for example, we study how novels emerged from traditional autobiographies, rather than the other way around-Smith and Watson's concise overview is ideal in supporting this discussion (1-19) —and that's one of many reasons why it's erroneous to use "novel" as a catch-all term for "book" or "narrative." This work has a pragmatic as well as theoretical function, because by learning this disciplinary vocabulary students are better 
equipped to map the scholarly conversations of the field as they need to do as part of their original research: they learn possible search terms to use in databases of scholarly publications.

2. Autobiographical Truth: Our discussions about terminology necessarily have elements of definition: what is or is not "auto/biography"? What about the "autobiographical"? One of the expectations students do have is that these kinds of texts are "true," and by true they mean many other things- "unmediated," and "authentic," but also sometimes "objective," reflecting a pervasive commitment to ideas that such "truths" actually exist: post-modern understandings that have shaped contemporary humanities ideologies have not, it seems, gained similar traction outside the academy. Even my fourthyear students have, it turns out, a deep and uncritical commitment to this ideal Truth; despite recent popular framing of a "post-truth" era, or "fake news," and their own digital practices-such as the use of filters on Instagram-that highlight the "staged" nature of selfrepresentations, they remain uncritically optimistic that there can be one, true account. This belief connects in tacit ways to concerns many students raise about autobiographical texts as "biased" and "subjective," terms that we engage as reflecting cultural stereotypes about knowledge production. Such attitudes also illustrate a possible default assumption about the work life narratives do: they are not "literary," but historical, providing information, and the presence of narrative techniques seems antithetical (here students also have to confront uninformed ideas about the discipline of history as well as literary studies).

Understanding this commitment, I now spend more time talking about auto/biographical truth. Unlike the genres of fiction, we note, life narratives represent actual people and events; they are indeed referential - they "touch the world," in Paul John Eakin's terms. But they are personal narratives, I remind them, from the perspective of an individual or collective, that provide versions of events, that are emotionally truthful for the author (Smith and Watson 15-18). Here we underline once more the point that these texts are representations, not direct experience itself. We acknowledge the limits of such auto/ biographical truth, discussing hoax as violating those limits. James Frey's A Million Little Pieces remains another illustrative example for understanding not only the distinction drawn between auto/biographical truth and lying, but also the emotional as well as economic investment textual expectations carry. As part of this unpacking, we think about issues related to truth and that highlight the impossibility of a singular correct version. Who will be believed or not, we ask, and 
what are the costs of not being believed? Why does "truth" matter, and for whom? Who can get away with "truthiness," and who will be held to a higher standard? While I confess that I remain puzzled by this resistance to "truth" as being flexible, with these interventions, we do make some headway.

3. Genre: Implicit in these discussions of terminology and formal expectations is the concept of genre. To help students understand how these concepts connect, first I broaden students' expectations that genre relates specifically and only to form. We take up a rhetorical genre studies' definition, and talk about genre as comprised of form but also situation-that is, audience, purpose, and occasion (e.g., Coe and Freedman; Miller). Genres, as Carolyn Miller explains, do things in the world; they are social actions. In thinking about genre, we must ask questions of the texts we study, such as: When are the authors writing? In response to what kinds of cultural and social pressures? What do they want to do with their writing? Who do they need to hear them? How do they know what form to choose, and how to produce it? This kind of genre analysis is a really productive way to think about how subjects make choices, but also do so in a very particular context that might limit those choices, or that at the very least shape them. They are operating within literary and cultural traditions, and within cultural scripts for their subjectivities, which may or may not overlap with their choice of genres. Drawing from rhetorical genre studies' considerations of genre and power, we consider how genres are interested: that is, they serve someone else's interests, or, as Coe, Lingard, and Teslenko note, "they work for someone" (3). Taking up this idea, we examine the implications of genres as potentially bringing power and prestige, but also as part of hierarchies of belonging and privilege that may be exclusive or even damaging. For instance, as Gillian Whitlock notes, "memoir is a genre for those who are authorized and who have acquired cultural legitimacy" and "possess cultural capital" (21-22), and thus is not neccesarily accessible for all storytellers. Of course, the "uptake" (Freadman) of genres is unpredictable, because the production and consumption of narratives is transactional and dialogic. Thus we must understand genre in relation to the marketplace as part of the networks in which genres are created (and that they in turn create), and think about how texts move from authors to readers-no longer imagined but actual, responsive audiences.

4. Texts as commodities: Students have very little understanding of the book trade, and don't tend to think about texts as commodities that circulate in the global literary marketplace, as Gillian Whitlock 
reminds us (15). But this background is crucial, I think, to understanding texts and how they reflect and produce the cultures in which they move. To that end, we incorporate paratextual analysis (Genette): we study how texts are marketed-their jacket design, title, acknowledgements, etc., identifying how these materials-ones we tend to skip over as inconsequential - play significant parts in how we might approach a narrative. As part of a paratextual methodology, we analyze the reception of the texts we study, particularly looking at how amateur reviewers, actual consumers, talk about these texts, for example on websites such as Goodreads and Amazon. Here we can avoid speculative discussions about "the reader" (a universalized extrapolation based on how we ourselves have read) because we have evidence of how some real readers have understood and reacted to these texts. Such discussions generate questions about the role of the publishing industry in shaping not just the reception but perhaps the production of narratives. For example, we might ask how the corporate apparatus of a text can determine whose lives or stories will make "good products" at particular times and places. We think about how reading publics will receive, and perceive, life narratives is shaped by the socio-historic and cultural moment in which they are reading, with the result that the same text may be read quite differently at different times.

By way of closing, I share an exercise I designed that combines several of these concepts in a problem-based learning activity. I've used this activity in discussion of texts that challenge generic boundaries, in part because they don't seem to uphold expectations about truth, and are generically "messy" in ways that often frustrate readers. The exercise was inspired by Julie Rak's book Boom! Manufacturing Memoir for the Popular Market, which analyzes how "genre" is understood differently by the marketplace than by scholars and writers, and by Whitlock's exhortation to do the field work of studying how virtual and concrete bookstores merchandize life narratives (14-16), as well as by my own experience working as a bookseller. Most recently, I included this activity in a first-year course in which we studied Maxine Hong Kingston's Woman Warrior: Memoirs of a Girlhood Among Ghosts, a text that foregrounds "memoir" in its title (confusingly, though, in the plural rather than singular form), but that includes myth, history, and, the author tells us, fiction; to add to this imprecision, different editions are labelled differently by publishers: it is sold as "nonfiction," "fiction," or "memoir."

Telling and Selling Lives Exercise:

Students get into groups of 4 . They are given this scenario: 
- You're working at Pulp Fiction Books (an independent Vancouver bookstore). You receive a shipment of book orders for the store inventory that includes several copies of The Woman Warrior, a title the store has not carried before. You need to decide how to label the book and where in the store's sections to place it.

- Working with evidence (including page numbers for specific examples) from the book to support your decision-making, decide on a label (e.g., "memoir") and a location. You should think about what kinds of books it would be beside on the shelves, and how you would explain it to customers. What would be your one-sentence summary of this book that would make it sound compelling (and thus worth purchasing)?

- Once you've decided, jot down your responses and a justification for your choices. Be ready to share.

In the follow-up discussion, students have to defend their decisions. I introduce an angry customer who wants her money back because she'd been sold the book as a memoir and then it didn't seem to be that at all! We consider what makes this particular text hard to classify, and why the author would deliberately introduce such generic confusion. Why, we ask, do we think fantasy, fiction, and the mythic might be necessary to Maxine Hong Kingston's personal ("non-fictional") narrative, part of her autobiographical truth? In responding, the class has to grapple with how these texts make meaning (the choices the author makes), and how meaning is made of them by others (publishers, consumers). The exercise therefore offers an effective way to think about the "instructions for reading" writers give us, to use Smith and Watson's terms (236), what cultural as well as generic expectations readers bring to texts, and how writers' choices of genre are deliberate and productive, an essential aspect of the self-representation they are developing, even as those choices may not be understood or respected by the other parties involved in these textual transactions.

While these concepts have become central to my current teaching practice, reflecting what I have seen as integral points of confusion, this list must remain dynamic and responsive to student aptitudes and understandings. What I see as crucial is less the specific topics and more the work of making explicit to students our theoretical premises, of unpacking our disciplinary and specialist assumptions. With a conceptual framework, methodologies, and critical language in place, they may better see how to engage with these texts and the broader issues they address, and thus we support students in joining our conversations as informed participants. 


\section{WORKS CITED}

Coe, Richard, and Aviva Freedman. "Genre Theory: Australian and North American Approaches." Ed. Mary Lynch Kennedy. Theorizing Composition: A Critical Sourcebook of Theory and Scholarship in Contemporary Composition Studies. Westport, CT: Greenwood Press, 1998. 136-147.

Coe, Richard, Lorelei Lingard, and Tatiana Teslenko. "Genre as Action, Strategy, and Difference: An Introduction." Eds. Richard Coe, Lorelei Lingard, and Tatiana Teslenko. The Rhetoric and Ideology of Genre: Strategies for Stability and Change. Hampton, 2002. 1-10.

De Vries, Maggie. Missing Sarah: A Memoir of Loss. Canada, Toronto: Penguin, 2008.

Eakin, Paul John. Touching the World: Reference in Autobiography. New Jersey, USA: Princeton, UP 1992.

Freadman, Anne. "Uptake." Eds. Richard Coe, Lorelei Lingard, and Tatiana Teslenko. The Rhetoric and Ideology of Genre: Strategies for Stability and Change. Hampton, 2002. 39-53.

Frey, James. A Million Little Pieces. New York: Anchor, 2005.

Genette, Gérard. Paratexts: Thresholds of Interpretation. Cambridge UP, 1997.

Kingston, Maxine Hong. The Woman Warrior: Memoir of a Girlhood Among Ghosts. Alfred A. Knopf, 1976.

McNeill, Laurie, and Kate Douglas. "Heavy Lifting: The Pedagogical Work of Life Narratives." Eds. Laurie McNeill and Kate Douglas. Teaching Lives: Contemporary Pedagogies of Life Narratives. Routledge, 2018. 1-10.

Miller, Carolyn. "Genre as Social Action." Quarterly Journal of Speech 70 (1984): 151-167.

Parker, Deborah. "The Pedagogical Potential of Memoir in an Interdisciplinary Context." Eds. Laurie McNeill and Kate Douglas. Teaching Lives: Contemporary Pedagogies of Life Narratives. Oxford, UK: Routledge, 2018. 83-91.

Rak, Julie. Boom! Manufacturing Memoir for the Popular Market. Waterloo, ON, Canada: Wilfrid Laurie UP, 2013.

Smith, Sidonie, and Julia Watson. Reading Autobiography: A Guide for Interpreting Life Narratives. $2^{\text {nd }}$ edition. Minneapolis, MN, USA: University of Minnesota Press, 2010.

Whitlock, Gillian. Soft Weapons: Autobiography in Transit. Chicago, IL, USA: University of Chicago Press, 2006.

\section{ABOUT THE AUTHOR}

Laurie McNeill is a Senior Instructor in the Department of English Language and Literatures and Chair of Arts First-Year Programs at the University of British Columbia. Her research has focused on folk genres of auto/biography, including diaries, ephemera, and obituaries. Her recent work examines the intersection of the digital and the archival in how individuals and communities make meaning of themselves and others on social media. Her publications on digital life narrative include articles and chapters in Biography, Identity Technologies: Producing Online Selves (Wisconsin UP) and Genres in the Internet (John Benjamins), and, with John Zuern, Online Lives 2.0, a special issue of the journal Biography (2015). She has published research on teaching and learning, including Teaching Lives (2017, Routledge) she co-edited with Kate Douglas. 